\title{
Breeding biology in a population of Rufous-collared Sparrow (Zonotrichia capensis, Statius Müller, 1776) at different elevations in the Tropical Andes
}

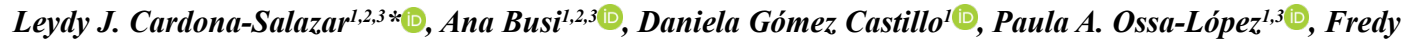 \\ A. Rivera-Páez ${ }^{1,3}$, Rodrigo A. Vásquez ${ }^{4}$ \& Gabriel J. Castaño-Villa ${ }^{2,3,5}$ \\ ${ }^{1}$ Universidad de Caldas, Departamento de Ciencias Biológicas, Manizales, Caldas, Colombia. \\ ${ }^{2}$ Universidad de Caldas, Grupo de Investigación en Ecosistemas Tropicales, Manizales, Caldas, Colombia. \\ ${ }^{3}$ Universidad de Caldas, Grupo de Investigación Gebiome, Manizales, Caldas, Colombia. \\ ${ }^{4}$ Universidad de Chile, Facultad de Ciencias, Departamento Ciencias Ecológicas, Santiago, Chile. \\ ${ }^{5}$ Universidad de Caldas, Departamento Desarrollo Rural y Recursos Naturales, Manizales, Caldas, Colombia. \\ *Corresponding author: Leydy J. Cardona-Salazar, e-mail: leydy.cardonasa@gmail.com
}

CARDONA-SALAZAR, L.J., BUSI, A.M., GÓMEZ CASTILLO, D., OSSA-LÓPEZ, P.A., RIVERA-PÁEZ, F.A., VÁSQUEZ, R.A., CASTAÑO-VILLA, G.J. Breeding biology in a population of Rufous-collared Sparrow (Zonotrichia capensis, Statius Müller, 1776) at different elevations in the Tropical Andes. Biota Neotropica 21(1): e20200985. https://doi.org/10.1590/1676-0611-BN-2020-0985

\begin{abstract}
Breeding biology in a population of Rufous-collared Sparrow (Zonotrichia capensis, Statius Müller, 1776) at different elevations in the Tropical Andes. Elevation strongly influences the evolution of life history traits associated with bird physiology and reproduction. Since life history traits in birds are modulated by environmental factors that vary with elevation, we expected to find changes in breeding biology traits of $Z$. capensis at different elevations. In this study, we compared the breeding biology (clutch size, egg volume, and reproductive activity) of a non-migratory population of Z. capensis in two localities at different elevations (low and high elevations, 1 $800 \mathrm{~m}$ a.s.1., and $3800 \mathrm{~m}$ a.s.l., respectively) and same latitude in the Colombian Tropical Andes for a one-year period. We found no differences in clutch size between the localities; however, egg volume was higher at high elevation. Furthermore, the reproductive activity differed significantly between localities. We propose that clutch size is likely conserved throughout the altitudinal distribution of $Z$. capensis since the species evolved in Tropical lowlands. On the other hand, the larger egg volume at high elevation could obey local environmental factors that may favor the reproductive success of the population.
\end{abstract}

Keywords: Pleistocene; phenology; paramo; life history; reproductive traits.

\section{Biología reproductiva en una población de Gorrión Copetón (Zonotrichia capensis, Statius Müller, 1776) a diferente elevación en los Andes tropicales}

Resumen: Biología reproductiva en una población de Gorrión Copetón (Zonotrichia capensis, Statius Müller, 1776) a diferente elevación en los Andes tropicales. La elevación influye fuertemente en la evolución de los rasgos de historia de vida asociados con la fisiología y reproducción de las aves. Dado que los rasgos de historia de vida en las aves están modulados por factores ambientales que varían con la elevación, esperábamos encontrar cambios en los rasgos de la biología reproductiva de Z. capensis a diferentes elevaciones. En este estudio, comparamos la biología reproductiva (tamaño de puesta, volumen del huevo y actividad reproductiva) de una población no migratoria de Z. capensis en dos localidades a diferente elevación (elevación baja $1800 \mathrm{~m} \mathrm{snm}$, y elevación alta $3800 \mathrm{~m}$ snm,) y a la misma latitud en los Andes tropicales colombianos por un período de un año. No encontramos diferencias en el tamaño de puesta entre las localidades; sin embargo, el volumen del huevo fue mayor en elevación alta. Además, la actividad reproductiva difirió entre las localidades. Proponemos que el tamaño de puesta probablemente se conserve en toda la distribución altitudinal de Z. capensis, ya que la especie evolucionó en las tierras bajas tropicales. Por otro lado, el mayor volumen del huevo a elevación alta podría obedecer a factores ambientales locales que pueden favorecer el éxito reproductivo de la población.

Palabras clave: Pleistoceno; fenología; páramo; historia de vida; rasgos reproductivos. 


\section{Introduction}

Understanding how life history traits are modeled by natural selection is one of the main questions in evolutionary ecology (Endler 1995). Moreover, environmental factors are relevant to explain the evolution of life history traits in birds (Lack 1968, Badyaev \& Ghalambor 2001). Changes in environmental conditions (e.g., temperature, atmospheric pressure, precipitation, and seasonality) that occur in response to variations in elevation and/or latitude have been related to life history evolution (Cody 1996, Boyce 1979, Endler 1986, Badyaev 1997a, Foster \& Endler 1999, Quirici et al. 2014). In particular, elevation is considered a factor that affects changes in clutch size, egg volume, and breeding season length in birds (Chabi et al. 2000, Lu 2011, Heming \& Marini 2015). However, to our knowledge, there are no population-level studies assessing different elevations at the same latitude in the Tropical region.

The relationship between variation in bird reproductive life history traits, such as clutch or egg size, and elevation remains unclear. For example, previous studies report larger, equal, and/or smaller clutches in breeding populations at high elevation compared to populations at lower elevation (Boyce et al. 2015, Boyle et al. 2016). Differences in life history traits are attributed to variations in climate, predation, and food limitation (Krementz \& Handford 1984, Kovshar 1981, Cody 1996, Boyce 1979). Particularly, in Tropical regions, there is insufficient information on how clutch size or egg volume responds to different elevations at the population level (Boyle et al. 2016), or on other reproductive life history traits.

The Rufous-collared Sparrow (Zonotrichia capensis Statius Müller, 1776) (Passerine, Emberizidae) is a socially monogamous bird with diverse life histories. This Neotropical passerine has among the largest elevational (from sea level to $4600 \mathrm{~m}$ a.s.l.) and latitudinal distributions (from Mexico to Chile) among birds, occupying a wide variety of environments and habitats, such as coastal, paramo, humid forest, and urban areas (Rising et al. 2010, Chapman 1940). Additionally, several studies report differences in life history traits related to reproduction, physiology, ecology, and behavior, among others, throughout its distribution range (Miller \& Miller 1968, Moore et al. 2004, Class et al. 2009, Van Dongen et al. 2010). Therefore, this species a good model for investigating differences in reproductive life history traits under contrasting environmental conditions related to elevation. In this study, we identified several differences in the reproductive biology of $Z$. capensis populations at different elevations in the Colombian Tropical Andes. Since life history traits in birds are modulated by environmental factors that vary with elevation, we expected to find changes in the breeding biology traits of $Z$. capensis at different elevations.

\section{Materials and Methods}

The Rufous-collared Sparrow has non-migratory populations in Colombia and is found within an elevational range from 1000 to 3700 $\mathrm{m}$ a.s.l. The sexes are similar in coloration and juveniles differ from adults in several plumage characteristics. At this latitude, individuals breed almost year-round with a locally-defined seasonality; clutch size is two eggs on average and eggs are incubated exclusively by the females (Hilty \& Brown 1986, Rising et al. 2011, Miller \& Miller 1968).

\section{Study site}

During a one-year period, from 2015 to 2016, we monitored Rufouscollared Sparrow populations in two localities on the western slope of the Colombian Central Andes at different elevations (1 800 and $3853 \mathrm{~m}$ a.s.l.) and similar latitude. In the study area, the species is a year-round resident and shows a continuous distribution. Both localities are located in the Chinchina River basin in the department of Caldas (Figure 1),

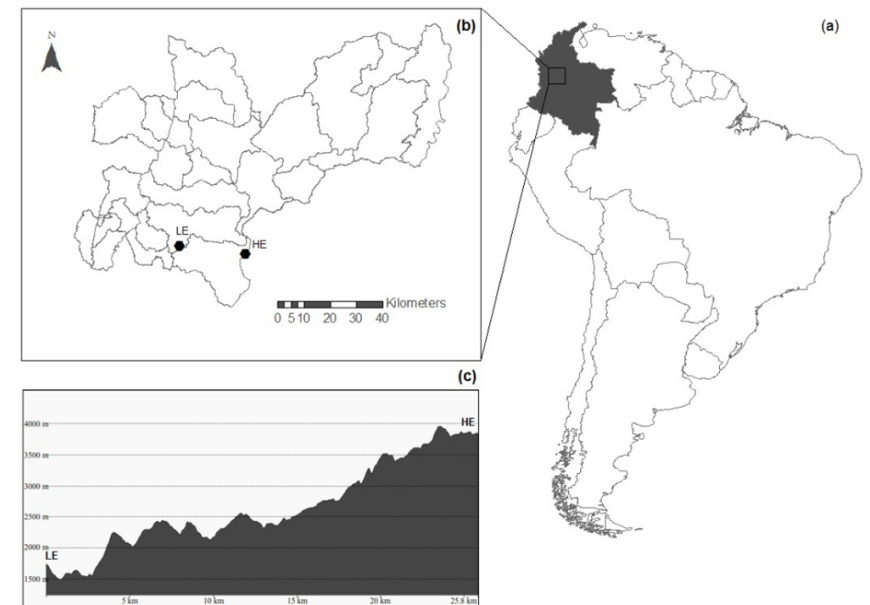

Figure 1. Locations of the study sites along the Chinchina River basin in the department of Caldas, Colombia. The triangle corresponds to LE, low elevation site (1 $800 \mathrm{~m}$ a.s.1.), and the hexagon corresponds to HE, high elevation site (3 $800 \mathrm{~m}$ a.s.1.).

where precipitation shows a bimodal pattern comprising a minor rainfall season, in relation to the annual average, during June-September and December-March and a major rainfall season occurring during AprilMay and October-November (Morales-Betancourt et al. 2012). The two sites, namely the low elevation locality (LE) (Alto del Naranjo: 500'29.8' $\mathrm{N}$ - 75'33'41.2' W; $1800 \mathrm{~m}$ a.s.1.) and high elevation locality (HE) (La Laguna: 458’49.3”'N - 75²0’06.8’'W; $3853 \mathrm{~m}$ a.s.1.), are separated in a straight line by $26 \mathrm{~km}$. Despite their proximity, these sites have different climate conditions (Busi et al. 2020). The LE locality is located in a coffee growing region with an average annual temperature of $20.7^{\circ} \mathrm{C}\left(\min .16 .8^{\circ} \mathrm{C}\right.$ and $\left.\max .26 .3^{\circ} \mathrm{C}\right)$ and annual rainfall of 2817 $\mathrm{mm}$. The HE locality is located in a paramo zone with an average annual temperature of $7.1^{\circ} \mathrm{C}\left(\min .4 .4^{\circ} \mathrm{C}\right.$ and $\max .10 .3^{\circ} \mathrm{C}$ ) and annual rainfall of $1848 \mathrm{~mm}$ (Federación Nacional de Cafeteros (F.N.C) n.d.). The HE locality was covered by a glacier during the Pleistocene until approximately 10000 years ago (Thouret et al. 1997).

\section{Field methods}

We visited each site every other day during one year (from December 2015 to December 2016; December 16 was day 1 of sampling). In each visit, nests were searched within an area of 13 ha to assess clutch size at each locality. The nests were visited every other day to establish the clutch size. Each egg was measured by its length and maximum width using a digital caliper $(0.03 \mathrm{~mm})$ to estimate egg volume (Hoyt 1979).

In the same period, we captured Rufous-collared Sparrow individuals using mist nets $(12 \times 2.5 \mathrm{~m} \times 36 \mathrm{~mm})$ to gather morphological evidence of the reproductive stage. The total sampling efforts were 1 
120 and 1680 hours net $^{-1}$ for LE and HE, respectively. We required a total sampling effort of 2800 hours due to low population densities of approximately two individuals per hectare observed at each locality. The captured birds were marked using bands with a unique color combination for later identification and the individuals were then released at the same capturing place.

We determined the onset of morphological indicators of reproductive stage (MIRS) in order to compare the reproductive activity of individuals from LE and HE localities for one year (Bears et al. 2009). Males were considered to be in reproductive stage when the cloacal protuberance (CP) measured at least $5 \mathrm{~mm}$ (Addis et al. 2010). On the other hand, in females, we checked for the presence of a brood patch (BP) since CP size is not a good indicator of MIRS (Miller \& Miller 1968).

\section{Data analysis}

To quantify differences in egg volume between the two elevations (high elevation vs. low elevation), we fitted a Linear Mixed Model (LMM) with the Gaussian error distribution using the lme4 R package (Bates et al. 2005). We included egg volume in $\mathrm{mm}^{3}$ as a response variable, elevation as a factor (LE and $\mathrm{HE}$ ), clutch size as a predictor (i.e., covariate), and nest identity as a random effect. Due to the reduced number of nests found in the study area, we compared the clutch size between HE and LE with Fisher's Exact Test ( $2 \times 2$ table). Specifically, we contrasted the frequency of nests with a single egg or more than two eggs between localities. We used circular statistics to compare the reproductive activity (MIRS) between both locations. The dates of MIRS were converted to Julian days and then to radians. The reproductive activity data were fitted to density kernels for each locality. Then, we compared the reproductive activity using the overlap coefficient (i.e., high coefficient values indicated more similar activities). The circular statistics analyses were done using the activity (Rowcliffe 2019) and overlap (Ridout \& Linkie 2009) R packages. All the procedures and statistical analyses were performed in R 3.6.1 (R Development Core Team 2019).

\section{Results}

We observed nests with eggs at LE in three months (April, July, and October, $n=6$ ) and at HE in three months (April, May, and June, $n=$ $6)$. Clutch size ranged from one $(n=2)$ to two $(n=4)$ eggs at HE and two $(n=4)$ to three $(n=2)$ eggs at LE, with a mode of two eggs at each elevation. There was no significant difference in clutch size between elevations (Fisher's Exact Test, $P=0.454$ ). Rufous-collared sparrow females layed eggs of size $22.2 \pm 0.64 \mathrm{~mm}$ length and $16.6 \pm 0.81 \mathrm{~mm}$ width $(n=10)$ at high elevation, and $21.4 \pm 0.86 \mathrm{~mm}$ length and $15.3 \pm$ $0.66 \mathrm{~mm}$ width $(n=15)$ at low elevation. The mean egg volume at $\mathrm{HE}$ was $3147.7 \mathrm{~mm}^{3}(\mathrm{SD}=346.9)$ and at low elevation it was $2545.6 \mathrm{~mm}^{3}$ $(\mathrm{SD}=277.6)$ (Figure 2). We found a statistically significant difference in mean egg volume between elevations, indicating that larger eggs were found at high elevation compared to smaller eggs at low elevation (Table 1). In addition, the LMM also indicated a non-statistically significant relationship between egg volume and clutch size (Table 1).

We captured a total of 46 adult individuals, including 26 and 20 at low and high elevation localities, respectively. At HE, we obtained 19 records of reproductive activity (15 individuals, three recaptures). The highest peaks of reproductive activity occurred in February and September (Figure 3). Moreover, at the LE, we found 24 records of

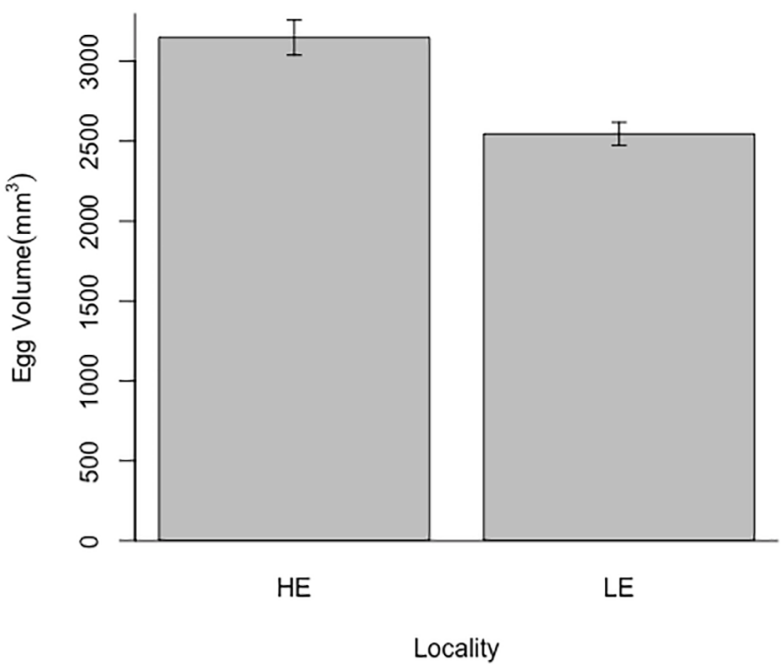

Figure 2. Mean values for egg volume in two localities at different elevations, high elevation (HE) and low elevation (LE). Errors bars represent the standard deviations of the mean.

Table 1. Results of the Linear Mixed Model (LMM) to test differences in egg volume in response to elevation and clutch size. The contrast represents the statistically significant difference between Low Elevation (LE) and High Elevation (HE).

\begin{tabular}{cccc}
\hline Fixed effects & B (SE) & t-value & $\boldsymbol{p}$-value \\
\hline Intercept (HE) & $3450.51(295.03)$ & -11.69 & $<0.01^{* * *}$ \\
Contrast (LE-HE) & $-453.80(193.75)$ & -2.34 & $0.04^{*}$ \\
Clutch size & $-171.831(156.68)$ & -1.09 & 0.29 \\
\hline Random effects & $\sigma 2$ & & \\
\hline Nest Identity & 33909 & - & - \\
Residuals & 61858 & - & - \\
\hline
\end{tabular}

MIRS (22 individuals, two recaptures). Reproductive activity peaks occurred in January, March, July, October, and December (Figure 3). Moreover, the reproductive activity peaks at high elevation occurred before those at low elevation. We found a low reproductive activity overlap between low and high elevations (Figure 3) and the reproductive activity differed significantly between both localities $(=0.35, \mathrm{P}<0.001)$.

\section{Discussion}

We did not find variations in clutch size in relation to elevation. This result disagrees with the findings of Cody (1966) and Winkler (2004). Both authors have suggested changes in clutch size with elevation in the Tropical region, due to the extreme environmental conditions that the individuals experience at high elevation. In particular, changes in clutch size can be associated with low food availability and high energy requirements for reproduction (Badyaev 1997b, Boyle et al. 2016). The Rufous-collared Sparrow populations studied here did not show differences in clutch size. The Rufous-collared Sparrow originated in the Tropical lowlands (Lougheed et al. 2013) so it is likely that clutch size in this species was optimized for lowlands, where a clutch of two is common among near-equatorial locations (Eikenaar et al. 2013, Miller $\&$ Miller 1968). Furthermore, this clutch size is conserved by individuals inhabiting a higher elevation. This could be associated with the low 


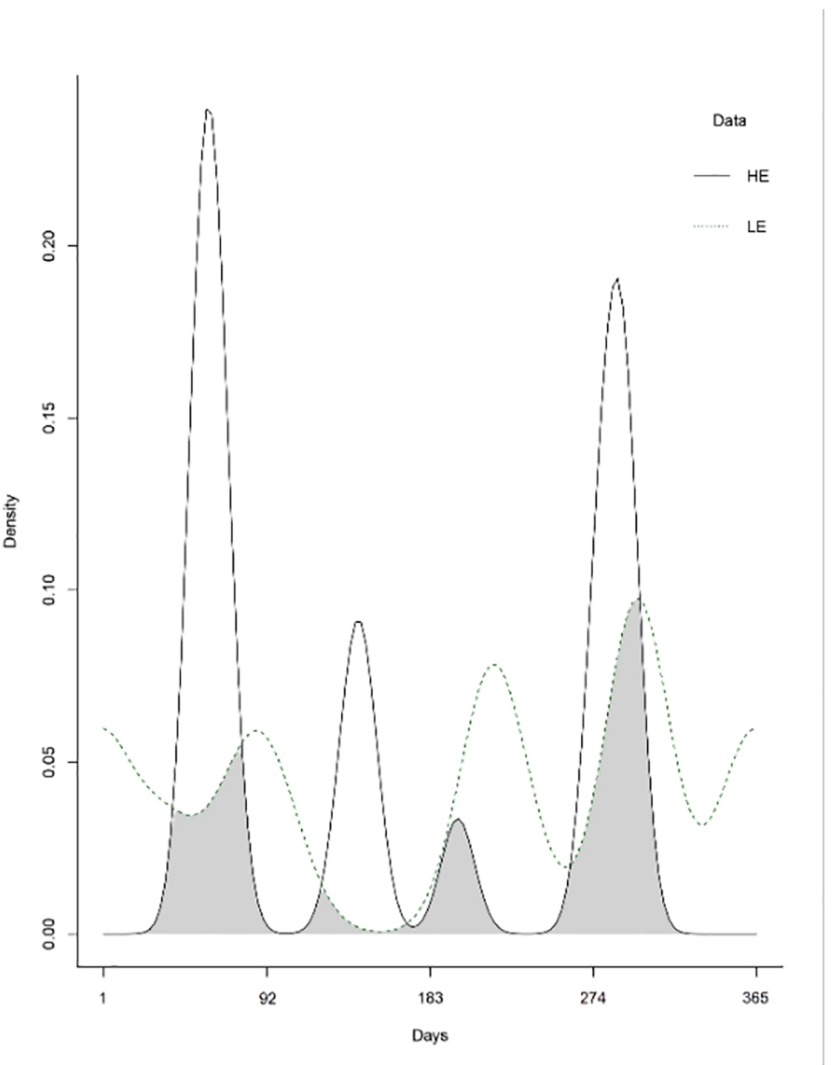

Figure 3. Reproductive activity kernels for high (HE) and low (LE) elevations. Activity kernel curves represent record density throughout 365 days (December 16 was day 1 of sampling).

variability in clutch size observed in our results. In addition, Z. capensis likely colonized the locality at HE in this region less than 10000 years ago, which could be an evolutionarily short time for the appearance of changes in clutch size associated with environmental factors.

The larger egg volume found at high elevation is possibly explained by the embryonic temperature hypothesis, which proposes that egg volume is larger when these are incubated at low environmental temperature and for longer periods due to the energetic requirements of the embryos (Martin 2008). Another possible explanation is that larger eggs lose heat more slowly during incubation recesses because of the lower surface area-to-volume ratio (Rhymer 1988). Larger eggs likely provide an advantage to brood survival in harsh or lowquality environments (Smith \& Bruun 1998, Styrsky et al. 1999, Lu 2005). Therefore, larger egg volumes at HE may be related to higher reproductive investment in this trait to possibly produce higher quality offspring (Bears et al. 2009).

The greater amount of evidence of reproductive activity in fewer peaks at HE than LE could be regulated by environmental factors. In fact, local environmental factors, such as rainfall, temperature, and food availability, are supplementary cues that can influence the timing and length of the reproductive season and the development of cloacal protuberance in males (Lack 1966, Wingfield \& Kenagy 1991).We found three peaks of reproductive activity at each elevation; two of them occurred at the beginning of the major rainfall season, i.e., March and October, and the other peak occurred during the minor rainfall season, specifically, in July. It is possible that harsher environmental conditions limited the length of the reproductive activity at the high elevation locality as opposed to the low elevation.

Overall, the environment can be an important factor of natural selection, leading to population-level responses to altitudinal gradients in the Tropics. Our results suggest that the Rufous-collared Sparrow that evolved in the lowlands preserves clutch sizes even at different altitudes. As a result, egg volume may have increased at HE to locally favor the reproductive success of the population. However, due to the reduced sample size of our study, these results should be considered with caution.

The negative relationship between clutch size and egg volume found here is similar to that reported by (Heming and Marini 2015). It has been proposed that high energy requirements for reproduction produce a trade-off between clutch and egg size, whereby egg volume decreases as clutch size increases (Stearns 1992; Williams 2012), as it was observed in our study population.

\section{Acknowledgments}

To the Vicerrectoría de Investigaciones y Posgrados of Universidad de Caldas for funding the project titled "Variación en los niveles de testosterona de acuerdo a la duración del período reproductivo en una población de copetón, Zonotrichia Capensis, a diferente altitud en los Andes tropicales" code: 0627416. To RAV acknowledges the support of FONDECYT 1140548,PFB-23-CONICYT and CONICYT- AFB170008. To EL for their collaboration in statistical analysis. This research was developed under the Framework Agreement for Collection of Specimens of Wild Species of the Biological Diversity with noncommercial scientific research purposes (ANLA Resolution No. 1166).

\section{Author Contributions}

Leydy J. Cardona-Salazar (Corresponding Author) performed a substantial contribution in the concept and design of the study; contribution to data collection; contribution to data analysis and interpretation and; contribution to manuscript preparation.

Ana Busi performed a substantial contribution in the concept and design of the study; contribution to data collection; contribution to data analysis and interpretation and; contribution to manuscript preparation.

Daniela Gómez Castillo performed a contribution to data collection and; contribution to data analysis and interpretation.

Paula A. Ossa-López performed a contribution to data analysis and interpretation; contribution to manuscript preparation.

Fredy A. Rivera-Páez performed contribution to manuscript preparation; contribution to data analysis and interpretation.

Rodrigo A. Vásquez performed a contribution to critical revision, adding intellectual content.

Gabriel J. Castaño-Villa performed a substantial contribution in the concept and design of the study; contribution to data analysis and interpretation; contribution to manuscript preparation and; contribution to critical revision, adding intellectual content.

\section{Conflicts of Interest}

The authors declare that they have no conflict of interest related to the publication of this manuscript. 


\section{Data availability}

Dryad, https://datadryad.org/stash/share/dFvmhb6MTtGsbA3E0OXRnLkkaHqpNQ0CqpreJ82mCc4

\section{References}

ADDIS, E.A., BUSCH, D.S., CLARK, A.D. \& WINGFIELD, J.C. 2010 Seasonal and social modulation of testosterone in Costa Rican rufouscollared sparrows (Zonotrichia capensis costaricensis). Gen. Comp. Endocrinol. 166(3):581-589.

BADYAEV, A. a. V. 1997a. Covariation between life history and sexually selected traits: an example with cardueline finches. Oikos 80(1):128-138.

BADYAEV, A. V. 1997b. Avian life history variation along altitudinal gradients: An example with cardueline finches. Oecologia 111(3):365-374.

BADYAEV, A. V \& GHALAMBOR, C.K. 2001. Evolution of Life Histories along Elevational Gradients: Trade-Off between Parental Care and Fecundity. Ecology 82(10):2948-2960.

BATES, D., MÄCHLER, M., BOLKER, B., WALKER, S. 2015. Fitting Linear Mixed-Effects Models Using lme4. J. Stat. Softw., 67(1), 1-48. doi: $10.18637 /$ jss.

BEARS, H., MARTIN, K. \& WHITE, G.C. 2009. Breeding in high-elevation habitat results in shift to slower life-history strategy within a single species. J. Anim. Ecol. 78(2):365-375.

BOYCE, A.J., FREEMAN, B.G., MITCHELL, A.E. \& MARTIN, T.E. 2015. Clutch size declines with elevation in tropical birds. Auk 132(2):424-432.

BOYCE, M.S. 1979. Seasonality and Patterns of Natural Selection for Life Histories. Am. Nat. 114(4):569-583.

BOYLE, A.W., SANDERCOCK, B.K. \& MARTIN, K. 2016. Patterns and drivers of intraspecific variation in avian life history along elevational gradients: A meta-analysis. Biol. Rev. 91(2):469-482.

BUSI, A., CARDONA-SALAZAR, L.J., GÓMEZ CASTILLO, D., OSSALÓPEZ, P.A., RIVERA-PÁEZ, F.A., VÁSQUEZ, R.A. \& CASTAÑOVILLA, G.J. 2020. Morphological differences in a population of Rufouscollared Sparrow (Zonotrichia capensis, Statius Müller, 1776) (Passerine, Emberizidae) at different elevations in the Tropical Andes. Biota Neotrop. 20(2): e20190867.

CHABI, Y., BENYACOUB, S. \& BAŃBURA, J. 2000. EGG-size variation in algerian populations of the blue Tit (Parus caeruleus ultramarinus): Effects of altitude and habitat. Rev. d'Ecologie (La Terre la Vie) 55(2):183-192.

CHAPMAN, F. 1940. The post-glacial history of Zonotrichia capensis. Bull. Am. Museum Nat. Hist. 77381-439.

CLASS, A.M., MOORE, I.T., WALTERS, J.R., KELLEY, M.J. \& FRASER, J.D. 2009. Rufous-Collared Sparrows. (November):

CODY, M.L. 1966. A General Theory of Clutch Size. Evolution (N. Y). 20(2):174.

EIKENAAR, C., BONIER, F., MARTIN, P.R. \& MOORE, I.T. 2013. High rates of extra-pair paternity in two equatorial populations of rufous-collared sparrow, Zonotrichia capensis. J. Avian Biol. 44(6):600-602.

ENDLER, J.A. 1986. Natural Selection in the Wild. Princeton ed. Princeton.

ENDLER, J.A. 1995. Multiple-trait coevolution and environmental gradients in guppies. Trends Ecol. Evol. 10(1):22-29.

FEDERACIÓN NACIONAL DE CAFETEROS (F.N.C). Anuario metereológico cafetero.

FOSTER, S.A. \& ENDLER, J.A., eds. 1999. Geographic variation in behavior: perspectives on evolutionary mechanisms and adaptive functions. Oxford Uni ed. New York.

GRIFFITHS, R., DOUBLE, M.C., ORR, K. \& DAWSON, R.J.G. 1998. A DNA test to sex most birds. Mol. Ecol. 7(8):1071-1075.

HEMING, N.M. \& MARINI, M.Â. 2015. Ecological and environmental factors related to variation in egg size of New World flycatchers. J. Avian Biol. 46(4):352-360.

HILTY, S.L. \& BROWN, W.L. 1986. A Guide to the Birds of Colombia. Princeton ed. Princeton.
HOYT, F. 1979. Practical methods of estimating volume and fresh of bird eggs. Auk 96(January):73-77.

KOVSHAR, A.F. 1981. Peculiarities of the bird reproduction in subalpine: on the material of Passeriformes in the Tien Shan. Acad. Sci. Kazakh SSR.

KREMENTZ, D.G. \& HANDFORD, P. 1984. Does avian clutch size increase with altitude? Oikos 43256-259.

LACK, D. 1966. Population Studies of Birds. 1st ed. ed. Oxford University Press.

LACK, D. 1968. Ecological adaptations for breeding in birds. London: Methuen.

LOUGHEED, S.C., CAMPAGNA, L., D A VILA, J. e a, TUBARO, P.L., LIJTMAER, D. i o a, \& HANDFORD, P. 2013. Continental phylogeography of an ecologically and morphologically diverse neotropical songbird, Zonotrichia capensis. BMC Evol. Biol. 13(1):58.

LU, X. 2005. Reproductive ecology of blackbirds (Turdus merula maximus) in a high-altitude location, Tibet. J. Ornithol. 146(1):72-78.

LU, X. 2011. Reproductive ecology of three Tibetan waterbird species, with special reference to life-history alterations along elevational gradients. Zool. Stud. 50(2):192-202.

MARTIN, T.E. 2008. Egg size variation among tropical and temperate songbirds: an embryonic temperature hypothesis. Proc. Natl. Acad. Sci. U. S. A 105(27):9268-9271.

MILLER, A.H. \& MILLER, V.D. 1968. The Behavioral Ecology and Breeding Biology of the Andean Sparrow, Zonotrichia Capensis. Caldasia 10(47):83-154

MOORE, I.T., WALKER, B.G. \& WINGFIELD, J.C. 2004. The effects of combined aromatase inhibitor and anti-androgen on male territorial aggression in a tropical population of rufous-collared sparrows, Zonotrichia capensis. Gen. Comp. Endocrinol. 135(2):223-229.

MORALES-BETANCOURT, J. a., CASTAÑO-VILLA, G.J. \& FONTÚRBEL, F.E. 2012. Resource abundance and frugivory in two manakin species (Aves: Pipridae) inhabiting a reforested area in Colombia. J. Trop. Ecol. 28(05):511-514.

QUIRICI, V., VENEGAS, C.I., GONZÁLEZ-GÓMEZ, P.L., CASTAÑOVILLA, G.J., WINGFIELD, J.C. \& VÁSQUEZ, R.A. 2014. Baseline corticosterone and stress response in the Thorn-tailed Rayadito (Aphrastura spinicauda) along a latitudinal gradient. Gen. Comp. Endocrinol. 19839-46.

R DEVELOPMENT CORE TEAM. 2019. R: A language and environment for statistical computing, reference index version 3.6.1. Foundation for Statistical Computing, Vienna, Austria.

RHYMER, J.M. 1988. The effect of egg size variability on thermoregulation of Mallard (Anas platyrhynchos) offspring and its implications for survival Oecologia 75(1):20-24.

RIDOUT, M.S., \& LINKIE, M. 2009. Estimating overlap of daily activity patterns from camera trap data. J Agr Biol Envir St 14:322-337.

RISING, J., JARAMILLO, A., COPETE, J., MADGE, S. \& RYAN, P. 2010. Familia Emberizidae (Buntings and New World Sparrows). In Handbook of the Birds of the World (del H. J, E. A, \& S. J, eds) Lynx Edicions, Barcelona, p.894.

RISING, J., JARAMILLO, A., COPETE, J., MAGDE, S. \& RYAN, P. 2011. Familia Emberizidae (Buntings and New World Sparrows). In Handbook of the birds of the world, Tanagers to New World Blackbirds (J. del Hoyo, A. Elliott, \& D. Christie, eds).

ROWCLIFFE, M. 2019. activity: Animal Activity Statistics. R package version 1.2., https://CRAN.R-project.org/package=activity.

SMITH, H.G. \& BRUUN, M. 1998. The effect of egg size and habitat on starling nestling growth and survival. Oecologia 115(1-2):59-63.

SOKAL, R.R. \& ROHLF, F.J. 1995. Biometry. Third ed. W. H. Freeman Company, New York.

STEARNS, S.C. 1992. The evolution of life histories. - Oxford University Press, Oxford, UK

STYRSKY, J.D., ECKERLE, K.P. \& THOMPSON, C.F. 1999. Fitness-related consequences of egg mass in nestling house wrens. Proc. R. Soc. Biol. Sci. 266(1425):1253. 
THOURET, J.C., VAN DER HAMMEN, T., SALOMONS, B. \& JUVIGNÉ, E. 1997. Late quaternary glacial stades in the Cordillera Central, Colombia, based on glacial geomorphology, tephra-soil stratigraphy, palynology, and radiocarbon dating. J. Quat. Sci. 12(5):347-369.

VAN DONGEN, W.F.D., MALDONADO, K., SABAT, P. \& VÁSQUEZ, R.A. 2010. Geographic variation in the repeatability of a personality trait. Behav. Ecol. 21(6):1243-1250.

WILLIAMS, T.D. 2012. Physiological adaptations for breeding in birds. Princeton University Press.
WINGFIELD, J.C. \& KENAGY, G.J. 1991. Natural regulation of reproductive cycles. In Vertebrate Endocrinology Fundamentals and Biomedical Implications (M. Schreibman \& R. E. Jones, eds) Academic Press, New York.

WINKLER, D.W. 2004. Nest, Eggs, and Young: Breeding Biology of Birds. In Handbook of bird biology (S. Podulka, R. Rohrbaugh, \& R. Bonney, eds) Ithaca.

Received: $28 / 02 / 2020$

Revised: 04/08/2020

Accepted: 11/11/2020

Published online: 18/12/2020 